\title{
B7H4 expression in tumor cells impairs CD8 T cell responses and tumor immunity
}

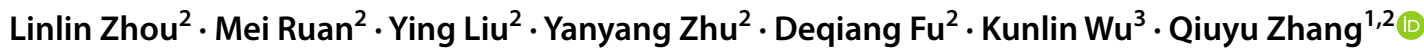

Received: 23 January 2019 / Accepted: 9 December 2019 / Published online: 17 December 2019

(c) The Author(s) 2019

\begin{abstract}
B7 homolog 4 (B7H4) is considered a negative regulator of immune responses, but the immunoregulatory role of B7H4 in the tumor microenvironment is not clear. Here, we assessed B7H4 expression cell types in human breast cancer tissues and addressed its potential mechanisms in the CD8 T cell immune response. The results from flow cytometry and immunohistochemistry demonstrated that B7H4 was highly expressed in 26 out of $30(86.7 \%)$ breast invasive ductal carcinomas, and B7H4 surface expression on tumor cells was inversely correlated with CD8 T lymphocytes infiltration $(p<0.0001)$. In vivo, B7H4-overexpressing tumor cells showed enhanced tumor growth in immunocompetent mice with impaired CD8 T cell infiltration of the tumor. Further investigation showed that activation and expansion of CD8 T cells within the lymph nodes were suppressed in B7H4-overexpessing tumor-bearing mice. An in vitro killing assay showed that the cytotoxicity of CD8 $\mathrm{T}$ cells was inhibited in $\mathrm{B} 7 \mathrm{H} 4$-overexpressing tumor cells. These findings suggest that $\mathrm{B} 7 \mathrm{H} 4$ in tumor cells is a negative regulator of CD8 $\mathrm{T}$ cell activation, expansion and cytotoxicity, indicating that tumor cell-associated $\mathrm{B} 7 \mathrm{H} 4$ might be a target for $\mathrm{T}$ cell-based cancer immunotherapy.
\end{abstract}

Keywords B7 homolog $4 \cdot$ Tumor microenvironment $\cdot \mathrm{T}$ cell $\cdot$ Immune suppression $\cdot$ Adoptive transfer

$\begin{array}{ll}\text { Abbreviations } \\ \text { B7H4 } & \text { B7 homolog } 4 \\ \text { CFSE } & \text { Carboxyfluorescein diacetate succinimidyl ester } \\ \text { CTL } & \text { Cytotoxic T lymphocyte } \\ \text { FCM } & \text { Flow cytometry }\end{array}$

Part of this paper was presented at the 17th International Congress of Immunology, 19-23 October 2019, Beijing, China, and published as an abstract in the European Journal of Immunology [1].

Linlin Zhou and Mei Ruan contributed equally to this work.

Electronic supplementary material The online version of this article (https://doi.org/10.1007/s00262-019-02451-4) contains supplementary material, which is available to authorized users.

Qiuyu Zhang

qiuyu.zhang@fjmu.edu.cn

1 The School of Basic Medical Sciences, Fujian Medical University, Fuzhou, China

2 Institute of Immunotherapy, Fujian Medical University, No. 1 Xuefu North Road, Shangjie Town, Minhou County, Fuzhou 350122, China

3 The First Affiliated Hospital of Fujian Medical University, No. 20 Chating Middle Road, Fuzhou 350005, China

$\begin{array}{ll}\text { IHC } & \text { Immunohistochemistry } \\ \text { IDC } & \text { Invasive ductal carcinomas } \\ \text { PBMC } & \text { Peripheral blood mononuclear cell } \\ \text { TCR } & \text { T cell receptor } \\ \text { TAM } & \text { Tumor associated macrophage } \\ \text { TIL } & \text { Tumor infiltrating lymphocyte }\end{array}$

\section{Introduction}

B7H4 (also referred to as B7x or B7S1) was found in 2003 and identified as a member of the B7 family of immune cosignaling molecules [2-4]. Aberrant B7H4 expression has been observed in various types of human cancer tissues and is thought to be correlated with advanced stages, poor prognosis, and overall patient survival [5-7]. However, the actual immunoregulatory role of $\mathrm{B} 7 \mathrm{H} 4$ in the tumor microenvironment remains unclear. Most studies have shown that $\mathrm{B} 7 \mathrm{H} 4$ is a negative regulator in $\mathrm{T}$ cell responses during antitumor immunity $[4,8-10]$, whereas one study demonstrated that $\mathrm{B} 7 \mathrm{H} 4$ plays a promoting role in antitumor immunity [11]. These paradoxical results might be due to the difference in $\mathrm{B} 7 \mathrm{H} 4$ expressing cell types and mouse tumor models used in the experiments. 
The $\mathrm{B} 7 \mathrm{H} 4$ protein is known to be preferentially expressed in tumor cells of human cancer tissues [12-14]. However, it has also been detected in endothelial cells of small blood vessels and tumor-infiltrating myeloid cells $[5,15,16]$. Given what is now known about B7-H1 (PD-L1, programmed cell death 1 ligand 1) [17], examining B7H4 expression patterns and distribution in tumor microenvironment may provide additional insights into how $\mathrm{B} 7 \mathrm{H} 4$ works in human cancer and immune response.

Hence, we analyzed B7H4 expression in tumor tissues, para-tumor and adjacent normal tissues and PBMC (peripheral blood mononuclear cells) derived from 30 patients with IDC (invasive ductal carcinomas), to assess the B7H4 expression pattern in the tumor site and its correlation with $\mathrm{CD} 8 \mathrm{~T}$ cell infiltration. We further investigated the potential mechanisms of B7H4-overexpressing tumor cells in the CD8 $\mathrm{T}$ cell immune response, by the use of B7H4 overexpression mouse tumor models, T cell adoptive transfer and CD8 T cell killing assay.

\section{Materials and methods}

\section{Patients and sample preparation}

Tumor tissues, para-tumor and adjacent normal tissues and corresponding peripheral blood were obtained from 30 breast IDC patients who underwent surgery at the First Affiliated Hospital of Fujian Medical University from 2017 to 2018. None of these patients received preoperative radiotherapy or chemotherapy before surgery. Matching para-tumor tissues were defined as those $\leq 2.0 \mathrm{~cm}$ from the tumor edge and the adjacent normal tissues were procured at the most distant site from the resected specimen $(\geq 5.0 \mathrm{~cm}$ from the tumor edge). Fresh tissue samples were cut and nonenzymatically dissociated, and single cells were prepared according to a previously described protocol [18]. PBMC were isolated using Ficoll-Paque PLUS (GE Healthcare, USA) according to the manufacturer's instructions.

\section{Immunohistochemistry (IHC)}

Human breast tissues were fixed and paraffin-embedded following standard procedures. The sections were immunolabeled with mouse anti-human CD8 (4B11, 1:100, AbD Serotec, UK) and mouse anti-B7H4 (6H3, 1:1000) antibodies, followed by anti-mouse peroxidase kit (ImmPRESS ${ }^{\mathrm{TM}}$, USA) labeling, respectively, according to the manufacturer's instructions. Anti-B7H4 antibody $(6 \mathrm{H} 3)$ was produced in our lab.

\section{Tumor cell lines and tumor models}

Human breast cancer cell lines (MCF-7, SKBR-3 and MDAMB-468), mouse breast cancer cell lines (4T1, E0771), mouse glioma cell (GL261) and OVA transfection the EL4 thymoma cell (EG7) were cultured in RPMI-1640 or DMEM containing 10\% FBS (Sigma-Aldrich). B7H4-overexpressing tumor cells (GL261-B7H4 and EG7-B7H4) were prepared by transfection of the pcDNA-mB7H4 plasmid encoding full-length mouse B7H4. C57BL/6 mice were anesthetized and $5 \times 10^{5}$ GL261 or GL261-B7H4 tumor cells were injected into the right cerebral hemisphere of the brain at $4 \mathrm{~mm}$ depth below the surface of the scull using a Hamilton PB-600-1 Repeatable Dispenser. Tumor growth was monitored by bioluminescent imaging every 3-7 days using a Lumina XR imaging system (PerkinElmer), and the survival of mice was monitored daily. A total of $5 \times 10^{5} \mathrm{EG} 7$ or EG7-B7H4 cells were s.c. injected in the right flank of C57BL/6 mice or NSG mice. Tumor sizes were measured with digital calipers every 3 days and calculated using the equation $(l+w) / 2$, where $l$ and $w$ refer to the larger and smaller dimensions, respectively. The mice were sacrificed as death for humane treatment after tumors reached a size of $2.0 \mathrm{~cm}$ in each dimension.

\section{OT-I adoptive transfer experiment}

$\mathrm{T}$ cells were isolated from the spleens and lymph nodes of OT-I TCR (T cell receptor) transgenic mice by a Pan-Naive T Cell isolation kit (Stemcell Technologies, USA). Irradiated non-T cells ( $40 \mathrm{~Gy}$ ) were cultured with $3 \mathrm{ng} / \mathrm{ml}$ chicken egg ovalbumin (OVA) peptide 257-264 (Peptides International) for $1 \mathrm{~h}$, and then cocultured with OT-I T cells for $48 \mathrm{~h}$. Mice were randomized into different treatment groups when EG7/ EG7-B7H4 tumor diameters reached 5-8 $\mathrm{mm}$ and received an intravenous transfer of $2 \times 10^{6}$ activated OT-I cells on day 10. IL-2 $\left(2 \times 10^{4} \mathrm{IU} / \mathrm{mice}\right)$ was i.p. administered to mice on days 10,12 and 14 . For the in vivo $\mathrm{T}$ cell expansion study, activated OT-I cells were labeled with $5 \mu \mathrm{M}$ carboxyfluorescein diacetate succinimidyl ester (CFSE, Thermo Scientific, USA) before transfer, and then blood, spleen and lymph nodes were analyzed for flow cytometry.

\section{In vitro killing assay}

To analyze OT-I cell cytotoxicity, EG7 or EG7-B7H4 cells $\left(2 \times 10^{4}\right)$ were labeled with $3 \mu \mathrm{M} \mathrm{CFSE}$ as target cells, and then incubated with activated OT-I cells for $24 \mathrm{~h}$ at various effector-to-target ratios. To obtain tumor-specific cytotoxic T lymphocytes (CTLs), dendritic cells and CD8 T cells were isolated from the spleens and draining lymph nodes of 
GL261-bearing mice on day 7, respectively, using negative isolation microbeads (Miltenyi Biotec). CD8 T cells cocultured with tumor lysate pulsed-dendritic cells for 3 days. Viable CD8 T cells were purified with Lymphocyte-M (Cedarlane) and incubated with CFSE-labeled target cells (GL261/GL261-B7H4) for $24 \mathrm{~h}$. Killing effect was evaluated by a cell death marker (LIVE/DEAD ${ }^{\circledR}$ Fixable Dead Cell Stain kits, Thermo Scientific, USA) using flow cytometry. To observe the killing effect of CTLs under microscope, target cells (GL261/GL261-B7H4) were stained with $5 \mu \mathrm{M}$ acetoxymethyl esters (AM, Thermo Scientific, USA) and coculture with tumor-specific T cells for $24 \mathrm{~h}$. Live cell imaging and data analysis were performed using a Zeiss LSM 880 laser-scanning confocal microscope.

\section{Flow cytometry}

TILs (tumor-infiltrating lymphocytes) were isolated from freshly resected tumor tissue using Gentle MACS mechanical dissociator containing lysis buffer (Miltenyi Biotec) and enriched according to the Lymphocyte-M manufacturer's recommendations. ACK lysis buffer was used to lyse red blood cells. Cell suspensions from tissues were blocked with anti-mouse CD16/32 (TruStain fc ${ }^{\mathrm{TM}}$, USA) before staining. Cells were stained with antibodies against mouse CD3, CD4, CD8, MHCII, CD137, CD40L, CD45.2, B7H4, TCR-V $\beta 5.1$, CD25, Foxp3, IFN- $\gamma$, death marker and matched isotype controls, depending on the experiment. For intracellular cytokine staining, TILs were restimulated with $1 \mathrm{ng} / \mathrm{ml}$ OVA peptide 257-264 for $8 \mathrm{~h}$ in the presence of GolgiPlug (BD Bioscience, USA) before intracellular staining. Single cells from human tumor tissues were blocked with human FcR blocking reagent (Miltenyi Biotec, USA) and then stained with antibodies against human CD3, CD8, CD45 and B7H4, and with the death marker. These antibodies were obtained from eBioscience, Molecular Probes, or BD Biosciences. Samples were run on a BD FACSVerse ${ }^{\mathrm{TM}}$ (BD Biosciences, USA) and analyzed using FlowJo software (TreeStar, USA).

\section{Statistical analyses}

Statistical analysis was conducted using GraphPad PRISM software (GraphPad Software, Inc. Version 6.03). Numerical data were expressed as the mean \pm SEM except where otherwise noted. Statistical difference between groups was compared using Student's $t$ test or one-way ANOVA with Tukey's or Dunnett's multiple comparison test (tumor growth, phenotype comparisons). The log-rank and Wilcoxon tests were used to analyze the difference in survival time between groups. Values of $p<0.05$ were considered indicative of significance.

\section{Results}

\section{The association between B7H4 expression and CD8 $T$ cell infiltration in the tumor tissues}

The clinical pathological features of 30 primary and metastatic ductal breast cancers (primary, 26.7\%, 8 of 30 and metastases, $73.3 \%, 22$ of 30) were listed in Supplementary Table $1.26 / 30$ cases of IDC (86.7\%) were positive for B7H4 membrane-bound expression by flow cytometry. All B7H4 positive cells were only detected in the CD45-negative population from tumor and para-tumor tissues. The percentage of $\mathrm{CD} 45^{-} \mathrm{B} 7 \mathrm{H} 4^{+}$cells (gating on live cells) was higher in tumor tissues than that in para-tumor tissues $(p<0.001)$ (Fig. 1a). In addition, there was an inverse association between the proportion of $\mathrm{CD} 45^{-} \mathrm{B} 7 \mathrm{H} 4^{+}$cells and $\mathrm{CD} 3^{+} \mathrm{CD} 8^{+} \mathrm{T}$ cells in tumor tissues of 26 IDC cases $(p<0.0001)$, especially in the cases expressing high levels of $\mathrm{B} 7 \mathrm{H} 4\left(>20 \% \mathrm{CD}^{2} 5^{-} \mathrm{B} 7 \mathrm{H} 4^{+}\right.$ cells in live cell population, 14 cases, $p=0.0006$ ) (Fig. 1b). Immunohistochemical staining revealed a high level of B7H4 expression on the cell surface and in the cytoplasm of tumor cells. The number of the $\mathrm{CD} 8^{+}$TILs was significantly lower in carcinoma cases with high levels of B7H4 expression in tumor cells $\left(\mathrm{B} 7 \mathrm{H} 4^{\text {high }}\right)$ than in those with no B7H4 in tumor cells (B7H4 $\left.{ }^{\text {neg }}\right)$ (Fig. 1c).

\section{B7H4 expression in tumor cell lines}

Surface B7H4 expression was detected on human breast cancer cell lines (MCF-7, SKBR-3 and MDA-MB-468), but not on mouse breast cancer cell lines (4T1 and E0771) (Fig. 2a). Stable B7H4-overexpressing GL261 and EG7 tumor cell line clones were selected. FCM (flow cytometry) analyses showed that B7H4 overexpression did not affect the expression level of MHC class I (H-2Kb) on GL261 cells (Fig. 2b, left graphs) and that OVA peptide bound to MHC class I on EG7 cells (Fig. 2b, right graphs). The cell growth curve showed no significant difference in cell proliferation between each of the two selected tumor cell lines and their respective controls in vitro (Fig. 2c).

\section{B7H4 overexpression potentiated tumor growth in immunocompetent mice}

B7H4-overexpressing transduced and control murine tumor cells were implanted into syngeneic C57BL/6 mice. Bioluminescence imaging showed that the growth of GL261B7H4 tumor was faster than control tumor (GL261-mock) 11 days after tumor implantation (Fig. 3a, b, c left graph, $p=0.0095$ on day 11). Correspondingly, GL261-B7H4bearing mice died earlier than GL261-mock-bearing mice 
a

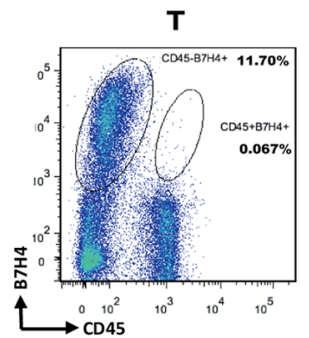

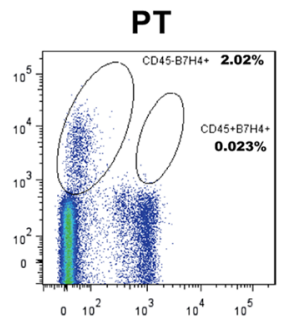
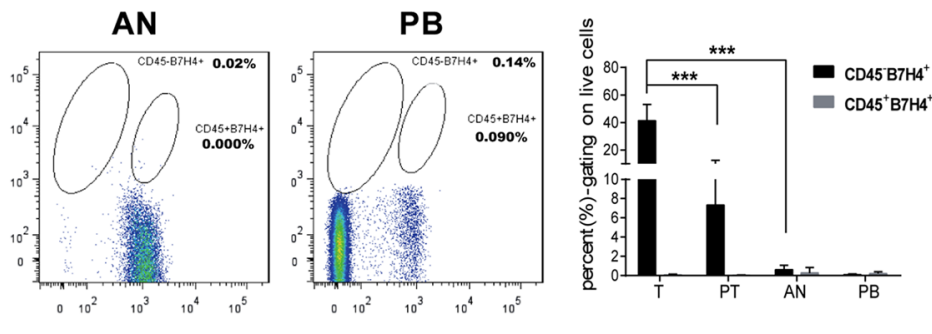

b
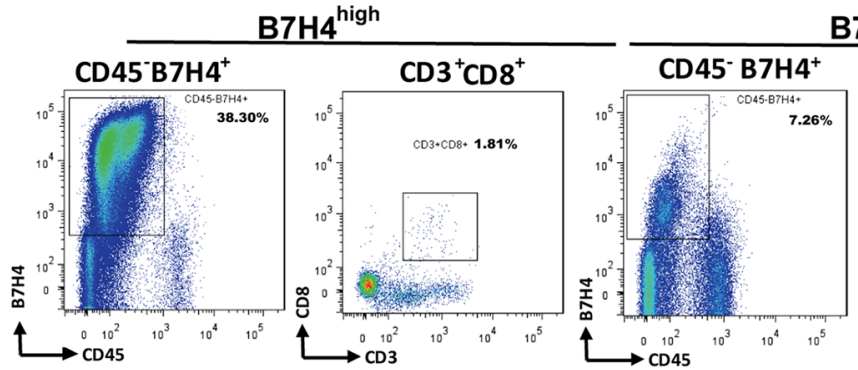

$\mathrm{B} 7 \mathrm{H} 4^{\text {low/neg }}$
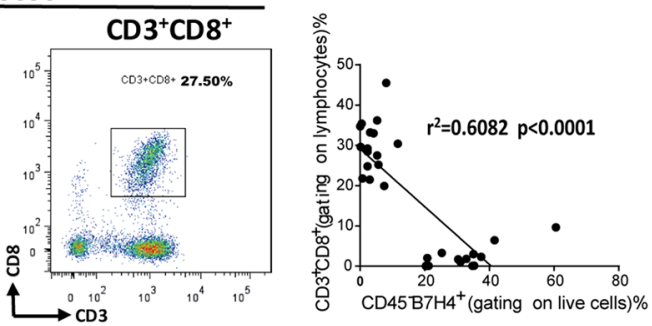

C

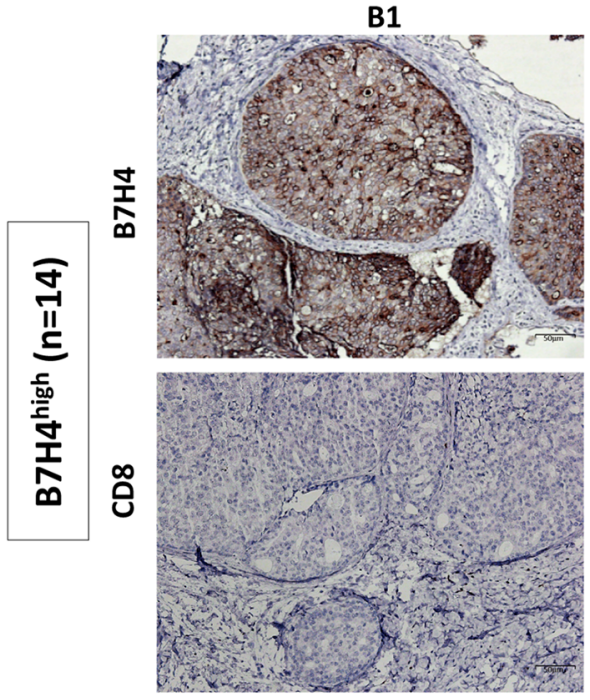

B2

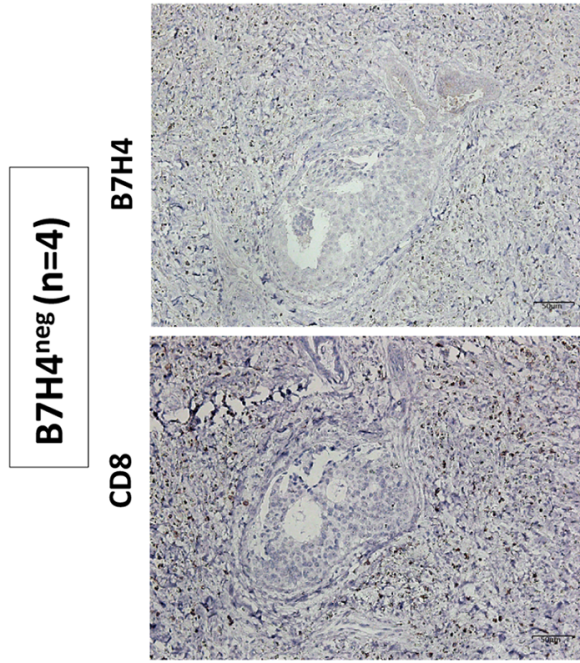

B3

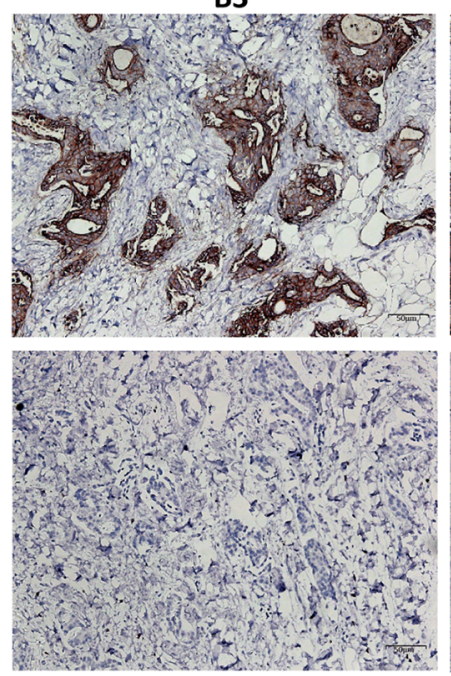

B7

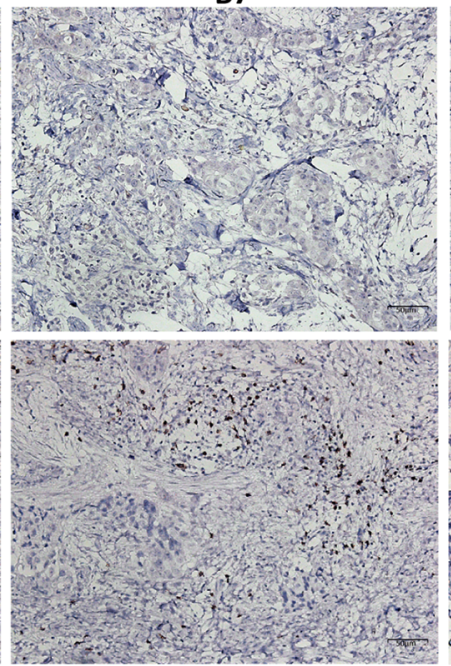

B4
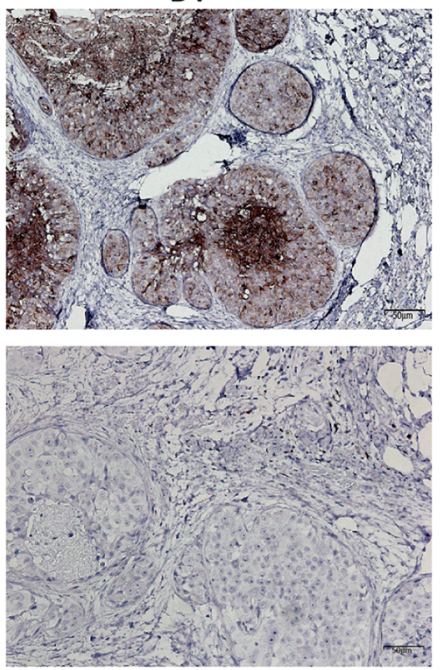

B8

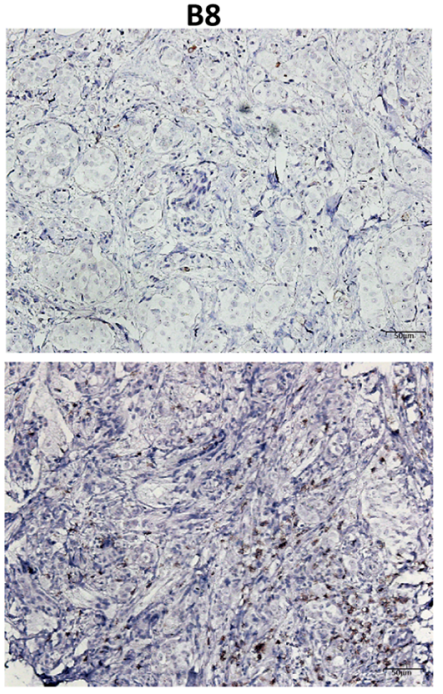


4Fig. 1 B7H4 expression and CD8 T cell infiltration in breast tumor tissues. a B7H4 expression was measured by flow cytometry in tumor tissues (T), para-tumor tissues (PT), adjacent normal tissues (AN), and peripheral blood mononuclear cells (PB) derived from patients with primary and metastatic ductal breast cancers. The percentage of $\mathrm{CD} 45^{-} \mathrm{B} 7 \mathrm{H} 4^{+}$cells and $\mathrm{CD} 45^{+} \mathrm{B} 7 \mathrm{H} 4^{+}$cells in different tissues (gating on live cells) were shown in representative FCM plots (left graph) and pooled from 8 cases with higher $\mathrm{B} 7 \mathrm{H} 4$ expression in tumor tissues $\left(\mathrm{CD} 45^{-} \mathrm{B} 7 \mathrm{H} 4^{+} \%>30 \%\right.$, right graph). The results were expressed as the mean of the percentage of $\mathrm{B} 7 \mathrm{H}^{+}{ }^{+}$cells $\pm \mathrm{SEM}$ in tissues or blood (*** $p<0.001)$. b Percentage of $\mathrm{CD} 45^{-} \mathrm{B} 7 \mathrm{H} 4^{+}$cells (gating on live cells) and $\mathrm{CD}^{+} \mathrm{CD}^{+}$(gating on lymphocytes) in breast tumor tissues were analyzed by flow cytometry. Representative FCM analysis plots from $\mathrm{B} 7 \mathrm{H} 4^{\text {high }}$ tumor tissues and $\mathrm{B} 7 \mathrm{H} 4^{\text {low/neg }}$ tumor tissues were shown in left graph. The correlation between the frequencies of $\mathrm{CD} 45^{-} \mathrm{B} 7 \mathrm{H} 4^{+}$cells and $\mathrm{CD}^{+} \mathrm{CD}^{+}$cells was shown in the right graph (30 cases of invasive ductal carcinoma). c Immunohistochemical staining of B7H4 and CD8 in breast cancer tissues. Strong B7H4 protein staining was detected in the tubular epithelium of tumor sections from 14 cases of invasive ductal carcinoma with a low density of infiltrating CD8 $\mathrm{T}$ cells (upper graph). Negative expression of B7H4 with a high density of infiltrating CD8 T cells was detected in tumor sections from 4 cases (lower graph). B7 $44^{\text {high }}$ :high expression of B7H4; $77 \mathrm{H} 4^{\text {low/neg }}$ :low or no expression of B7H4

(Fig. 3c, survival curve, $p=0.0013$ ). Similarly, B7H4 overexpression in EG7 tumor cells promoted tumor growth in immunocompetent mice resulting in decreased survival (Fig. 3d, e). However, when EG7-B7H4 and EG7-mock cells were implanted into immunodeficient NSG mice, there was no difference in tumor growth between the two types of tumor cells (Fig. 3f).

\section{B7H4 overexpression in tumor cells impaired CD8 T cell infiltration in a murine model}

To further examine the impact of B7H4 on the immune response and tumor microenvironment, tumor infiltrating lymphocytes from EG7-mock and EG7-B7H4-bearing mice were analyzed on day 21 . The frequency of $\mathrm{CD}^{+} \mathrm{CD}^{+} \mathrm{T}$ cells and OVA-specific CD8 T cells $\left(\mathrm{CD}^{+}{ }^{+} \mathrm{TCRV} \beta 5.1^{+}\right)$in the total tumor-infiltrating immune cell population $\left(\mathrm{CD} 45^{+}\right.$ live cells) were significantly reduced in EG7-B7H4 tumors compared to EG7-mock tumors (Fig. 4a, c). To assess the IFN- $\gamma$ production activity of CD8 $\mathrm{T}$ cells in tumor site, the intratumoral $\mathrm{T}$ cells from both tumors were stimulated with OVA-peptide for $8 \mathrm{~h}$ and intracellular staining of IFN- $\gamma$ was performed. The data revealed that the frequency of $\mathrm{CD}^{+} \mathrm{IFN}-\gamma^{+} \mathrm{T}$ cells in EG7-B7H4 tumors was also lower than that in EG7-mock tumors (Fig. 4d). However, there was no significant difference in the frequency of CD $4^{+}$Foxp $3^{+}$Treg cells from both mice (Fig. 4b).

\section{Activation and expansion of CD8 T cells were suppressed in EG7-B7H4 tumor-bearing mice}

To assess whether B7H4-mediated immune suppression can be reversed by the adoptive transfer of antigen-specific CD8 T cells, EG7-B7H4 and EG7-mock tumor-bearing mice were intravenously injected with activated CD8 OT-I cells on day 10. Unexpectedly, exogenous antigen-specific $\mathrm{T}$ cells significantly inhibited EG7-mock tumor cell growth but there was no change in EG7-B7H4 tumor growth (Fig. 5b). To explain why the adoptive transfer of CD8 T cells had no effect on EG7-B7H4 tumor-bearing mice, OT-I T cells were labeled with CFSE before transfer, and then lymphocytes derived from peripheral blood, spleen and draining lymph node were analyzed on the indicated day according to the schedule (Fig. 5a). Three days after adoptive transfer (day 13), the frequency of $\mathrm{CD}^{+} \mathrm{CD}^{+}$and $\mathrm{CFSE}^{+} \mathrm{CD} 8^{+} \mathrm{OT}-\mathrm{I}$ cells in the peripheral blood were higher in EG7-mock tumor-bearing mice than in EG7-B7H4 tumor-bearing mice (Fig. 5c). In EG7-mock tumor-bearing mice, the frequency of peripheral $\mathrm{CD}^{+}{ }^{+} \mathrm{CD} 3^{+}$and $\mathrm{CFSE}^{+} \mathrm{CD}^{+} \mathrm{OT}-\mathrm{I}$ cells were increased on day 17 and then decreased on day 20. However, in EG7-B7H4 tumor-bearing mice, the frequency of $\mathrm{CFSE}^{+} \mathrm{CD}^{+} \mathrm{OT}-\mathrm{I}$ cells gradually decreased after transfer (Fig. 5d). In the draining lymph node, at least five cell divisions of $\mathrm{CFSE}^{+} \mathrm{CD}^{+}$OT-I cells were detected in EG7-mock tumor-bearing mice, while fewer divisions of OT-I cells were detected in EG7-B7H4 tumor-bearing mice (Fig. 5e left graphs). However, no cell division was detected in the spleen (Fig. 5e right graphs), and no cell division was found in CFSE labeled $\mathrm{CD}^{-} \mathrm{T}$ cells derived from peripheral blood, draining lymph node or spleen. These results suggested that the proliferation of CD8 T cells within the lymph node was suppressed in EG7-B7H4 tumor-bearing mice. To analyze the activation of proliferating $\mathrm{T}$ cells in the lymph node, we stained lymphocytes with antibodies against MHCII, CD40L and CD137. As expected, more activated lymphocytes $\left(\mathrm{CFSE}^{+} \mathrm{MHCII}^{+}, \mathrm{CFSE}^{+} \mathrm{CD} 40 \mathrm{~L}^{+}\right.$and $\left.\mathrm{CFSE}^{+} \mathrm{CD} 137^{+}\right)$ were detected in EG7-mock tumor-bearing mice than in EG7-B7H4 tumor-bearing mice (Fig. 5f).

\section{B7H4-overexpressing tumor cells impaired the cytotoxicity of antigen-specific CD8 $\mathrm{T}$ cells}

The lack of an effect of the adoptive transfer of antigenspecific T cells on B7H4 tumor growth suggested that the cytotoxicity of CD8 T cells might be impaired in B7H4 tumor sites. An in vitro killing assay showed that compared to EG7-B7H4 cells, more EG7-mock cells in CFSE labeled population underwent lysis at higher effector: target ratios (50:1 and 100:1) (Fig. 6a). We next generated tumor specific cytotoxic CD8 T cells from GL261-bearing mice. Similarly, 
a
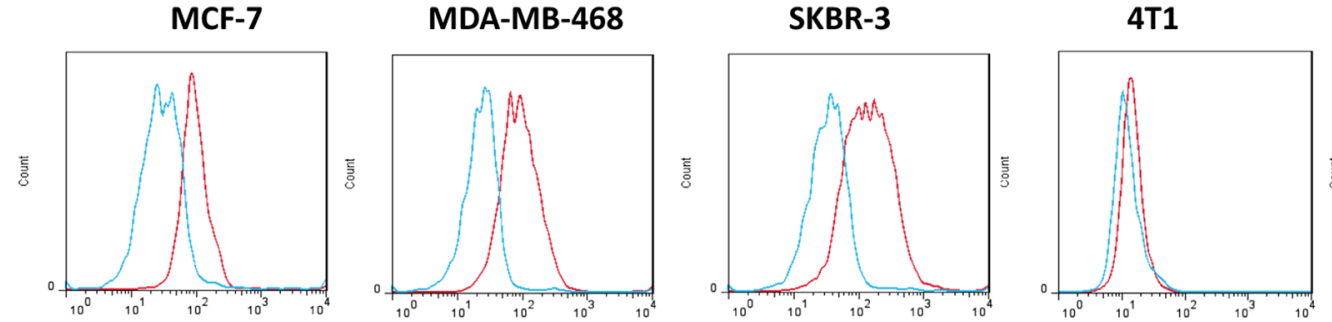

E0771

b
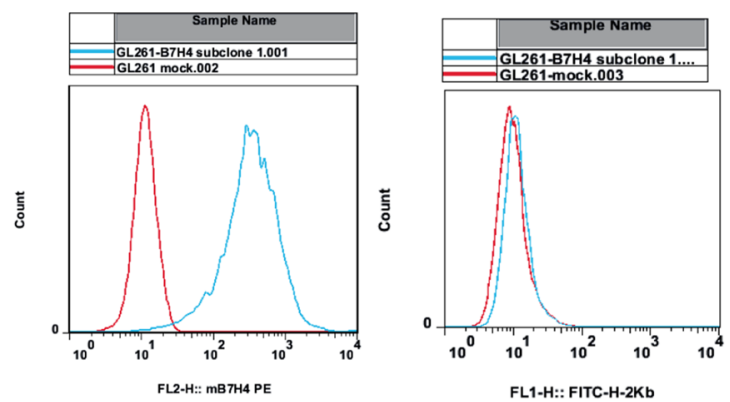

C

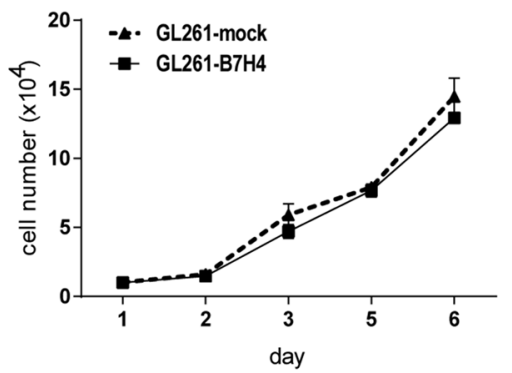

Fig. 2 Preparation of B7H4-overexpressing mouse tumor cell lines. a The expression of $\mathrm{B} 7 \mathrm{H} 4$ in human and mouse breast tumor cell lines was analyzed using anti-B7H4 antibodies by flow cytometry. b Two B7H4-overexpressing mouse tumor cell lines (GL261-B7H4 and EG7-B7H4) were confirmed by flow cytometry. MHC-I expression of GL261-B7H4 and OVA expression of EG7-B7H4 were analyzed

tumor specific CD8 T cells displayed a reduced killing ability toward GL261-B7H4 cells than to GL261-mock cells at optimal effector:target ratios (5:1 and 10:1) (Fig. 6b). Then in vitro imaging was used to confirm this phenotype. Correspondingly, more live cells were detected in GL261-B7H4 group than GL261-mock after coculture with CD8 T cells (Fig. 6c).

\section{Discussion}

The $\mathrm{T}$ cell inhibitory mechanisms of $\mathrm{B} 7 \mathrm{H} 4$ in the tumor microenvironment has not yet been resolved in detail. Kryczek suggested that human ovarian cancer-derived $\mathrm{B} 7 \mathrm{H} 4^{+}$ tumor-associated macrophage (TAM) suppress T cell proliferation and cytotoxicity [19]. Recently, Li et al. reported that B7H4 (B7S1) is highly expressed on tumor-infiltrating
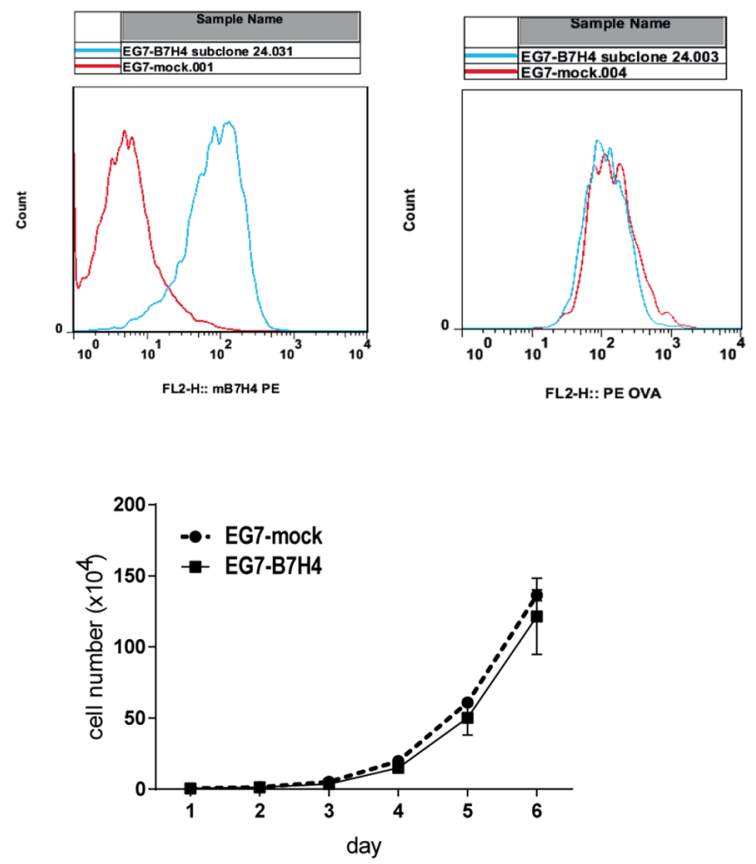

using anti-MHC class I (H-2 Kb) and anti-OVA257-264 (SIINFEKL) peptide bound to a $\mathrm{H}-2 \mathrm{~Kb}$ monoclonal antibody, respectively. c Growth curve of two B7H4-overexpressing cell lines (GL261-B7H4 and EG7-B7H4) compared with control cells (GL261-mock cells or EG7-mock cells)

myeloid cells and promotes the exhaustion of activated CD8 TILs in mouse Hepa1-6 bearing mice [16]. It is noteworthy that $\mathrm{B} 7 \mathrm{H} 4$ has been reported to be located in tumor cells but not immune cells in the majority of human cancer tissues by immunohistochemistry $[6,12,14]$. In the setting of antitumor immunity, cell surface $\mathrm{B} 7 \mathrm{H} 4$ overexpression is thought to play a dominant role. In previous studies, B7H4 expression was determined by immunohistochemistry. Here, we analyzed $\mathrm{B} 7 \mathrm{H} 4$ expression in a single cell suspension derived from fresh breast tumor, para-tumor and adjacent normal tissue samples by surface staining using flow cytometry. B7H4-positive cells were found in the CD45-negative cell population in breast tumor tissues, and no surface $\mathrm{B} 7 \mathrm{H} 4$ expression was detected in tumor-associated macrophages $\left(\mathrm{CD} 45^{+} \mathrm{CD} 68^{+}\right.$cell population) and tumor vasculature (CD45 ${ }^{-} \mathrm{CD} 31^{+}$cell population) (data not shown). IHC analysis further confirmed that $\mathrm{B} 7 \mathrm{H} 4$ expression was largely 
a

D4

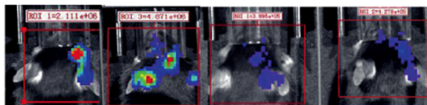

D11

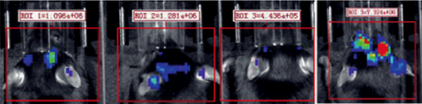

D20

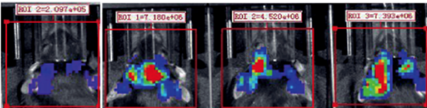

D24

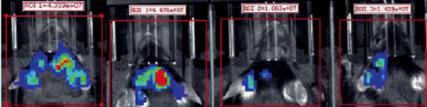

D29

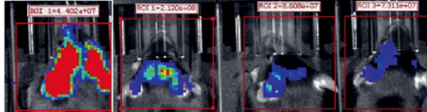

D35
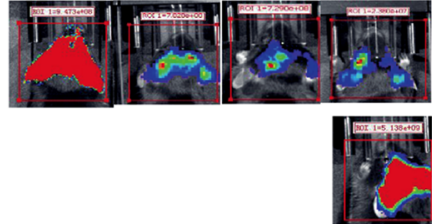

D39

b

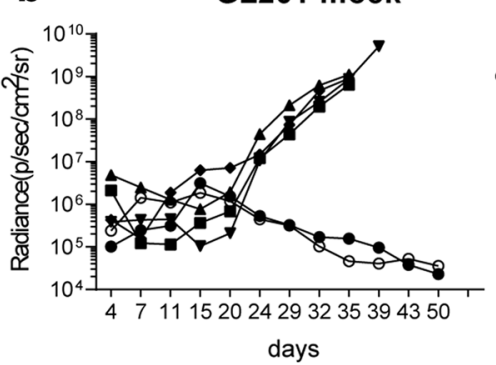

C

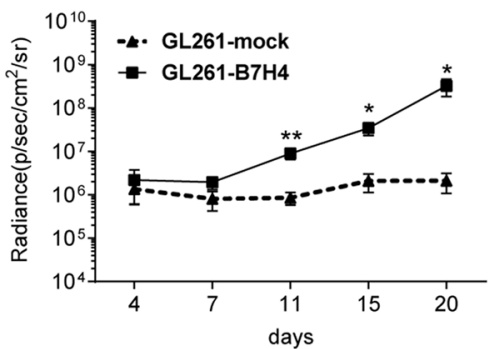

GL261-B7H4
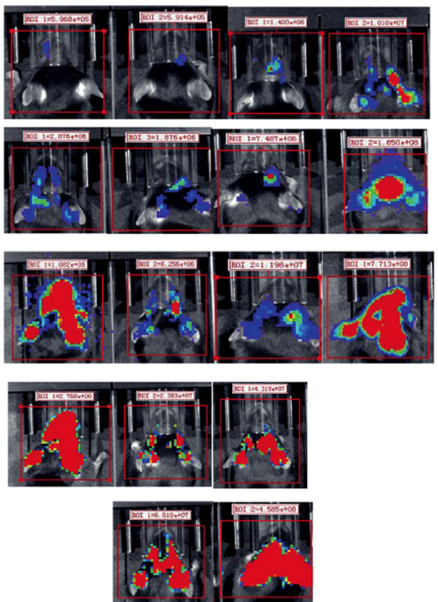

d

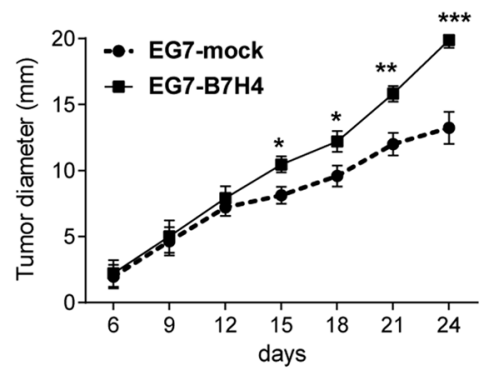

e

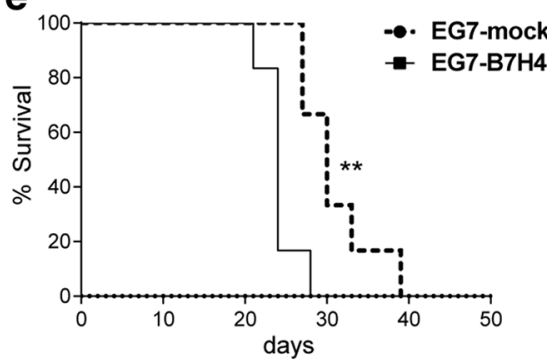

f
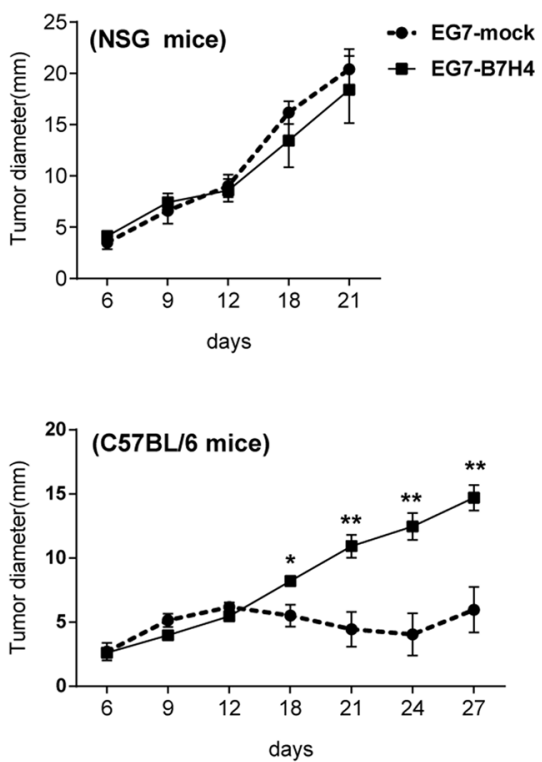

Fig. 3 Differences in tumor growth rates between B7H4-overexpressing and control tumors. a, b In vivo bioluminescent imaging and computer-obtained luminescence (photons/second) of each tumor model mouse implanted with firefly luciferase-transgenic GL261B7H4 cells or GL261-mock control cells. c Tumor growth and survival of GL261-B7H4 and GL261-mock bearing mice were recorded every 3-7 days; $n=6$, one representative example of two independent experiments was shown. d, e Tumor volumes and survival curve

restricted to the ductal epithelium of tumor tissues. Inconsistent with previous reports showing low intensity B7H4 for mice implanted with B7H4-overexpressing cells (EG7-B7H4) or EG7-mock cells, $n=5$. f Tumor growth in C57BL/6 mice or NSG mice injected with B7H4-overexpressing cells (EG7-B7H4) and EG7-mock cells. These two types of tumor cells were collected on the same passage before injection, $n=5$. Data are mean \pm SD from a single experiment, representative of two or three independent experiments. $* p<0.05 ; * * p<0.01$ and $* * * p<0.001$

staining in normal breast tissues [13, 20],we did not find B7H4 expression in adjacent normal breast tissues. Choi 
a
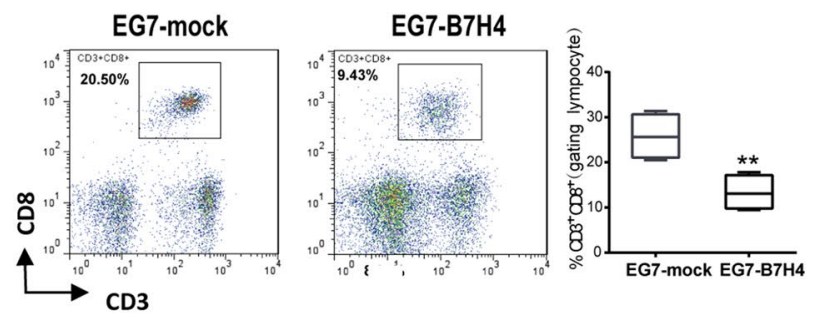

C
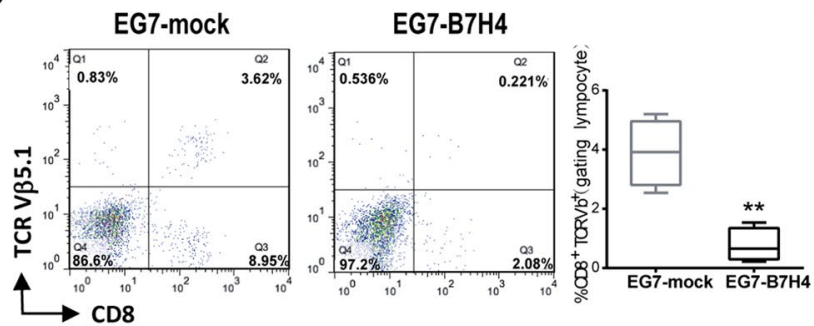

Fig. 4 The analysis of tumor-infiltrating T cells in EG7-B7H4 and EG7-mock tumor tissues. EG7-B7H4 and EG7-mock cells were subcutaneously injected into C57BL/6 mice and tumor-infiltrating immune cells were analyzed by flow cytometry on day 21 . The percentage of $\mathrm{CD}^{+} \mathrm{CD}^{+} \mathrm{T}$ cells $(\mathbf{a})$ and $\mathrm{CD} 4^{+} \mathrm{Foxp}^{+} \mathrm{T}$ cells $(\mathbf{b})$ in the lymphocyte population were shown as representative FCM plots

et al. also did not find $\mathrm{B} 7 \mathrm{H} 4$ expression in a range of normal tissues including breast tissue [2]. These results indicate that $\mathrm{B} 7 \mathrm{H} 4$ overexpression in breast cancer cells might be largely driven by oncogenic processes rather than antitumor immunity. More importantly, FCM results also showed an inverse correlation between $\mathrm{B} 7 \mathrm{H} 4$ surface expression on breast tumor cells and the percentage of $\mathrm{CD}^{+} \mathrm{CD}^{+}$cells, which was confirmed by IHC analysis. This inverse correlation has previously been reported in uterine endometrioid adenocarcinomas and non-small-cell lung cancer [21, 22]. These observations support the hypothesis that tumor-associated $\mathrm{B} 7 \mathrm{H} 4$ may function as a negative regulator of the $\mathrm{CD} 8$ $\mathrm{T}$ cell immune response. The central distribution of $\mathrm{B} 7 \mathrm{H} 4$ in breast tissues (high expression level in the center of the tumor tissues and low expression level in the para-tumor tissues) suggests that the inhibitory role of $\mathrm{B} 7 \mathrm{H} 4$ on the $\mathrm{CD} 8 \mathrm{~T}$ cell immune response is different from that of $\mathrm{B} 7-\mathrm{H} 1$ (PDL1). B7-H1 is known to be predominately expressed in the periphery of tumor cell conglomerates (interface distribution) and forms a shield at the periphery of the tumor tissue [17].

In an attempt to address the underlying immune mechanism of tumor surface B7H4 expression on CD8 T cell function, we sought to develop tumor models in immunocompetent mice using mouse tumor cell lines with surface B7H4 expression. Nevertheless, no constitutive surface B7H4 expression was found in all available mouse tumor cell lines; therefore, two B7H4-overexpressing clones were generated b
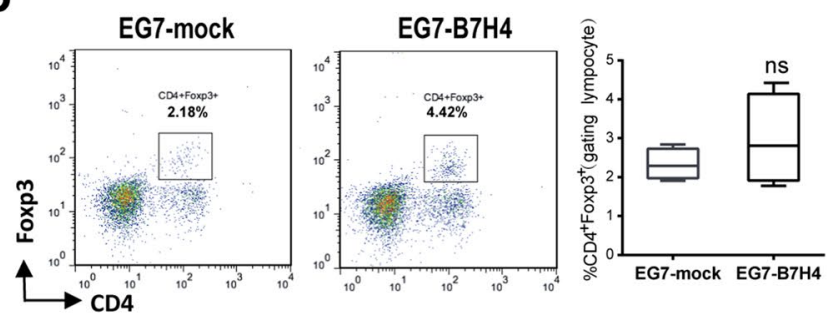

d
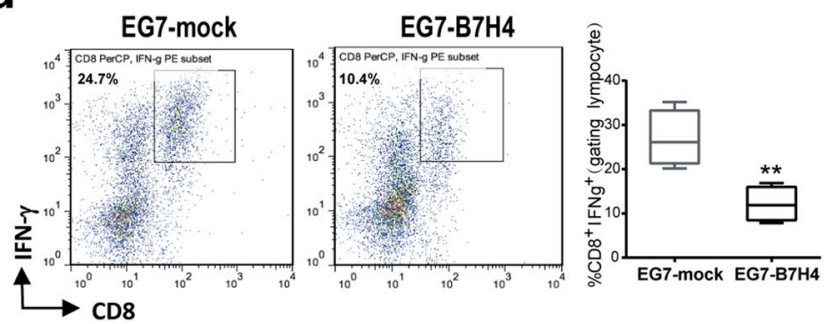

in two groups (left graph), and pooled from two independent experiments (right graph, $n=6$ ). $\mathbf{c}$ The percentages of TCRV $\beta 5.1$ staining in CD8 T cells derived from two groups were shown. d TILs were analyzed for cytokine production after stimulation with OVA-peptide, and the percentage of IFN $-\gamma^{+} \mathrm{CD} 8^{+} \mathrm{T}$ cells in the lymphocyte population were shown. $* * p<0.01$

in GL261 (mouse glioma) and EG7 (an OVA-transfected EL4 thymoma) cell lines. Intriguingly, B7H4 overexpression induced tumor growth in immunocompetent mice but not in immunodeficient NSG mice, indicating that overexpression of B7H4 in tumor cells might be a mechanism by which tumors could avoid eliciting an antitumor immune response. In our present study, no $\mathrm{B} 7 \mathrm{H} 4$ positive cell was detectable in the CD45-positive cell population of human breast cancer tissues and mouse tumor tissues derived from GL261- and EG7-bearing mice. Hence, we hypotheized that B7H4 overexpression in tumor cells might play a dominant role in the inhibition of $\mathrm{T}$ cell antitumor responses.

Although in vitro studies using immobilized B7H4 Ig fusion protein or cell-associated $\mathrm{B} 7 \mathrm{H} 4$ have suggested that B7H4 might deliver an inhibitory signal to T cells, thereby abrogating CD8 $\mathrm{T}$ cell proliferation and cytotoxicity [4], to data, little is known about how B7H4 impairs the T cell immune response in vivo. Hence, we analyzed the intratumoral T cells on day 21 in EG7-B7H4- or EG7-bearing mice. Our data revealed that $\mathrm{B} 7 \mathrm{H} 4$ overexpression in tumor cells decreased the frequency of antigen-specific CD8 T cells in the tumor site and reduced IFN- $\gamma$ production. To further investigate the dysfunction of effector CD8 T cells in EG7-B7H4-bearing mice, activated T cells (OT-I T cells) were adoptively transferred into EG7-B7H4- and EG7-mock tumor-established mice. As expected, adoptive transfer of OT-I cells inhibited EG7-mock tumor growth but had no effect on EG7-B7H4 tumor growth. Intriguingly, we found 
a

s.c. $0.5 \times 10^{6} \mathrm{cell} \mathrm{s} / \mathrm{mouse}$

EG7-mock or EG7-B7H4 i.v. OT-1 $\left(2 \times 10^{6}\right.$ cells/mouse $)$

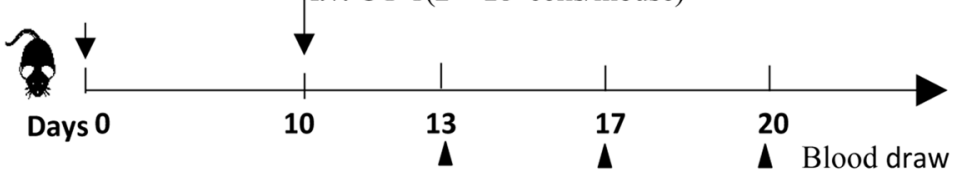

- Spleen LN harvest

C

(Day13)
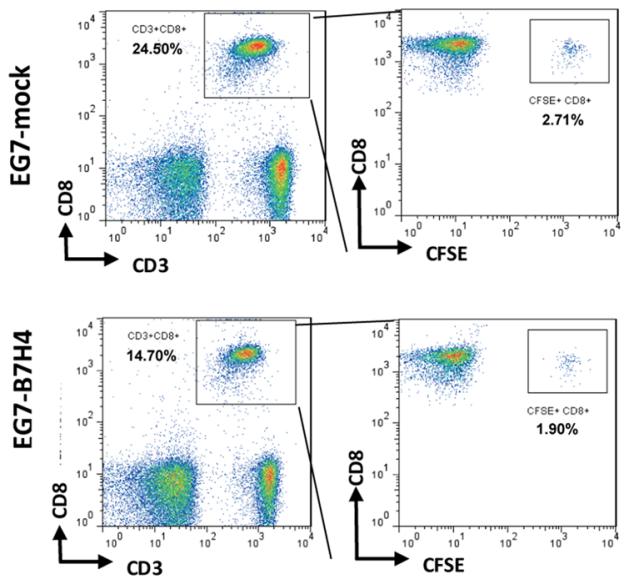

d
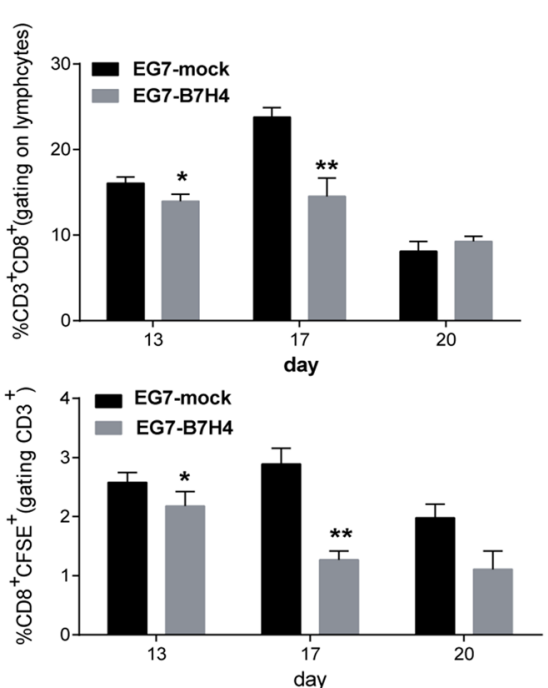

$\mathbf{e}$
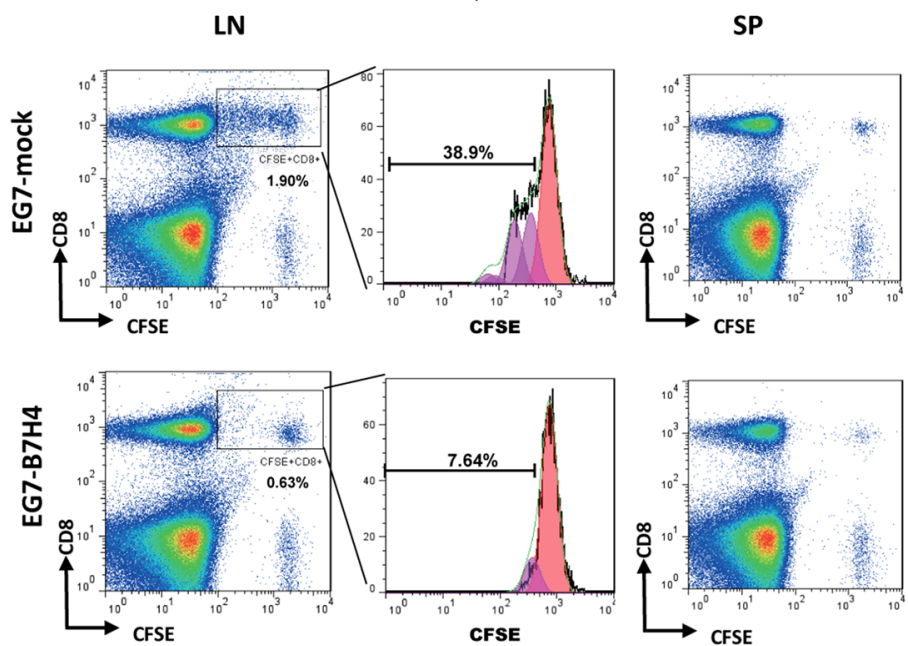

f
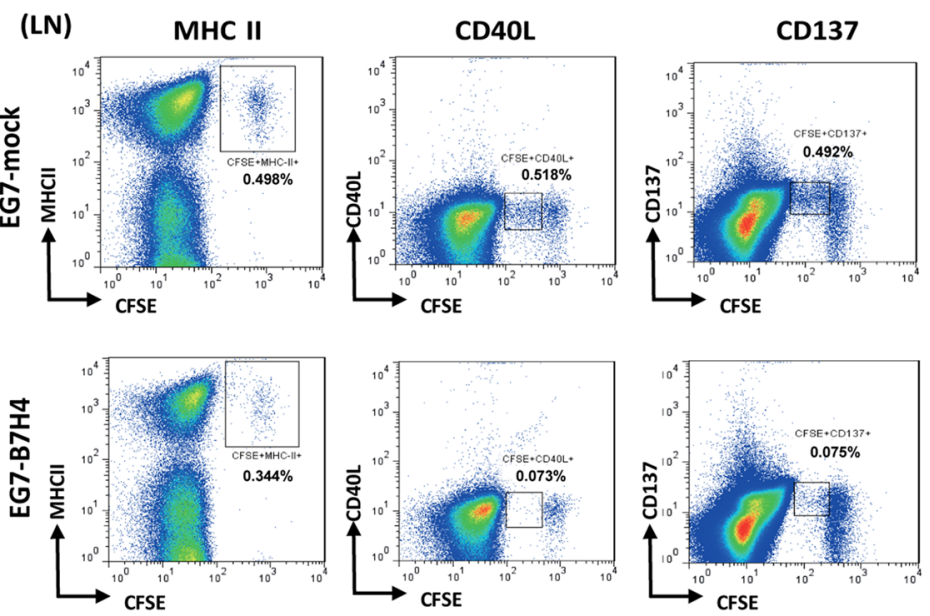

Fig. 5 The antitumor role of adoptively transferred CD8 T cells in EG7-B7H4 and EG7-mock tumor-bearing mice. a Treatment schema. C57BL/6 mice were subcutaneously implanted with EG7-B7H4 or control tumor cells (EG7-mock) in the right flank. Tumor-established mice were randomized into two groups when tumors reached $5-8 \mathrm{~mm}$ in the largest diameter (typically on day 10 after inoculation). The two groups intravenously received adoptive transfer of activated OT-I cells and i.p. IL-2 on day 10, 12, 14. For flow cytometric analysis, OT-I cells were labeled with CFSE before transfer. $\mathbf{b}$ Tumor growth curve of four groups. $\mathbf{c}$ The frequency of $\mathrm{CD} 3^{+} \mathrm{CD} 8^{+}$ and $\mathrm{CFSE}^{+} \mathrm{CD} 8^{+} \mathrm{T}$ cells (gating on the lymphocyte population and $\mathrm{CD}^{+} \mathrm{CD}^{+} \mathrm{T}$ cell population) in the peripheral blood of the treated mice (mice received adoptive transfer) on day 13 was shown in a representative FCM plot. d Average percentages of $\mathrm{CD}^{+} \mathrm{CD}^{+}$ and $\mathrm{CFSE}^{+} \mathrm{CD}^{+} \mathrm{T}$ cells on day 13 , day 17 and day 20 pooled from two independent experiments $(n=6$ mice per group). e The frequency of $\mathrm{CFSE}^{+} \mathrm{CD}^{+} \mathrm{T}$ cells (gating on the lymphocyte population) in the draining lymph node (LN) and spleen (SP) of the treated mice on day 20 were shown in representative FCM plots (left and right graph). The donor OT-I cell proliferation (gating on the $\mathrm{CD}^{+}$ $\mathrm{CFSE}^{+}$population) was analyzed by CFSE (middle graph). $\mathbf{f}$ The frequency of activated OT-I T cells $\left(\mathrm{CFSE}^{+} \mathrm{MHCII}^{+}, \mathrm{CFSE}^{+} \mathrm{CD}_{40 \mathrm{~L}}{ }^{+}\right.$, $\mathrm{CFSE}^{+} \mathrm{CD} 137^{+}$) in the draining inguinal lymph node of the treated mice were analyzed on day $20 . * p<0.05 ; * * p<0.01$ 
a
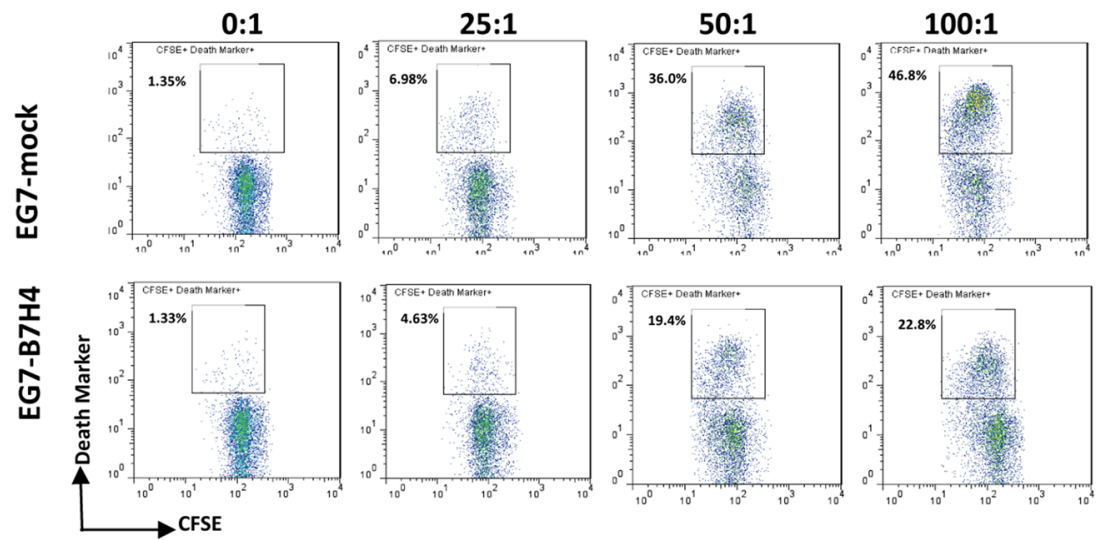

b
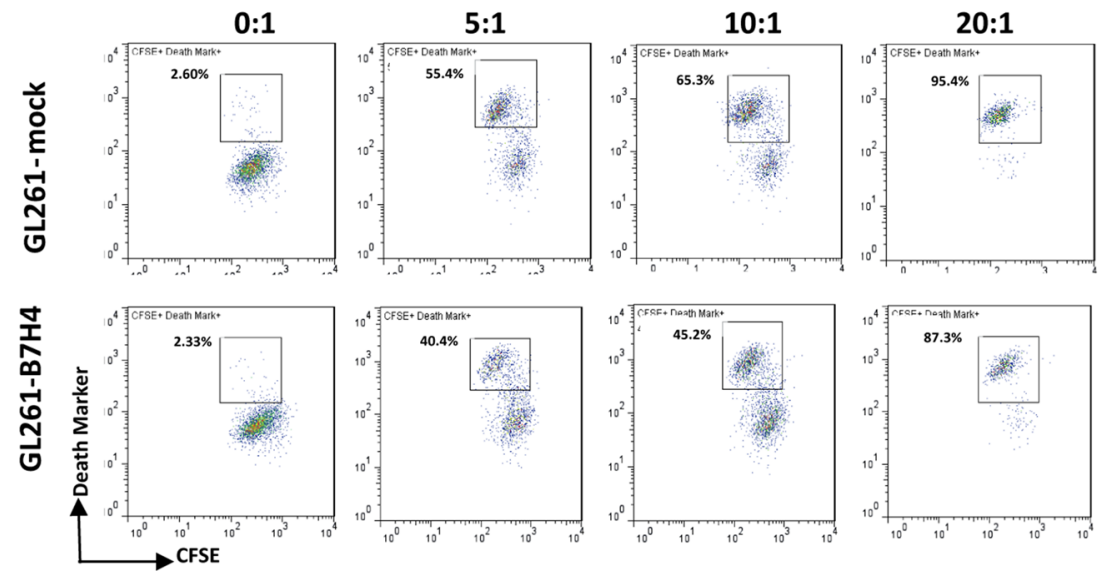

$5: 1$

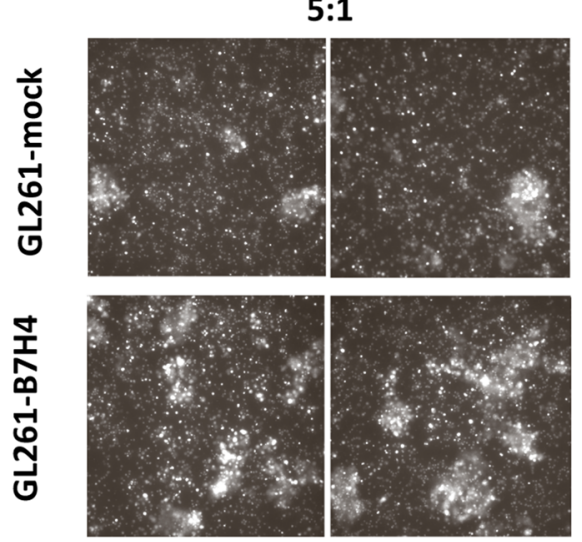

10:1
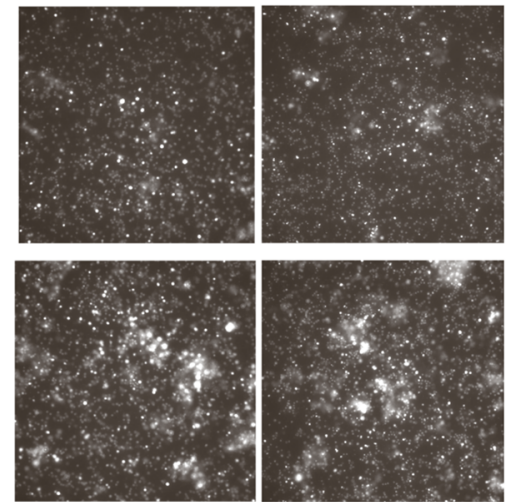
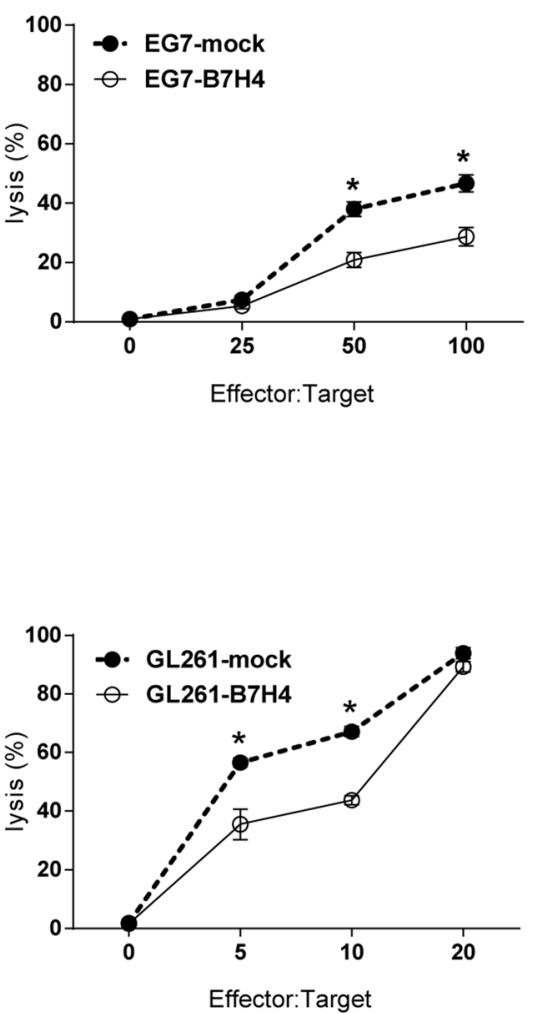

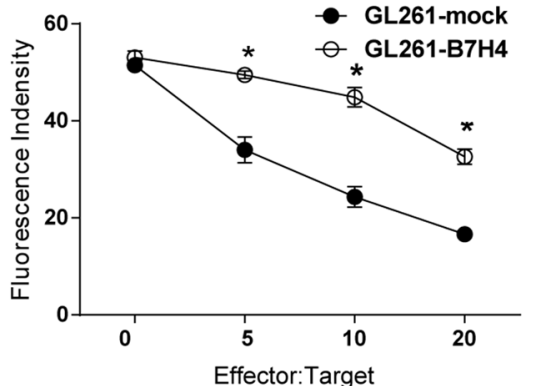

Fig. 6 The cytotoxic effect of CD8 T cells on B7H4-overexpressing and control tumor cells. a The cytolytic activity of purified CD8 OT-I cells against CFSE labeled target cells (EG7-B7H4 or EG7mock cells) was examined by FCM at the indicated effector:target cell ratios. The frequency of $\mathrm{CFSE}^{+}$Death-Marker ${ }^{+}$tumor cells (gating on the CFSE-positive population) was shown in representative FCM plots (left graph), and the percentage of lysed cells was pooled from two independent experiments (right graph). b Purified CD8 T cells from GL261-bearing mice were harvested on day 7 and stimulated with $\gamma$-irradiated dendritic cells pulsed with GL261 cell lysate for 3 days. Viable T cells were purified by LymphoLyte-M and used at the indicated effector:target (E:T) ratios against CFSE labeled target cells (GL261-B7H4 or GL261-mock cells) for the killing assay as described above. c To observe the lysis of target cells under a microscope, target cells (GL261-B7H4 or GL261-mock cells) were stained with acetoxymethyl esters (live marker) and then cocultured with GL261 tumor-specific T cells for $24 \mathrm{~h}$. Live cell imaging (left graph) and data analysis (right graph) were performed using a confocal microscope, $(\times 100$ objective). The lysis percentage was calculated as follows: $\%$ lysis $=100 \times$ Death-Marker ${ }^{+} \mathrm{CFSE}^{+}$target cells/total $\mathrm{CFSE}^{+}$target cells. All assays were performed in triplicate. The data are representative of at least two independent experiments. ${ }^{*} p<0.05$ 
that OT-I cells transferred into the mice implanted with EG7-B7H4 did not divide, while $\mathrm{CFSE}^{+} \mathrm{CD}^{+}$OT-I cells transferred into mice implanted with EG7-mock cells went through more than five divisions within 10 days. T cell surface marker analysis showed that all the divided CD8 OT-I cell were activated $\mathrm{T}$ cells $\left(\mathrm{MHCII}^{+} \mathrm{CD} 137^{+} \mathrm{CD} 40 \mathrm{~L}^{+}\right)$in EG7-mock tumor-bearing mice. Collectively, these results suggest that the ability of antigen-specific CD8 activation and expansion were impaired in mice implanted with B7H4overexpressing tumors. This finding offers an explanation for the failure of adoptive transfer of the OT-I cells to inhibit EG7-B7H4 tumor growth. Furthermore, B7H4 cell surface expression on both EG7 and GL261 mouse tumor cell lines suppressed CD8 T cell cytotoxicity in vitro.

In conclusion, the unique expression of $\mathrm{B} 7 \mathrm{H} 4$ in tumor cells and its inverse relationship with the number of tumorinfiltrating CD8 T lymphocytes in breast invasive ductal cancer tissues supports the inhibitory role of tumor surface B7H4 on T cell immune responses. In a mouse tumor model, B7H4 overexpression on the tumor surface fosters tumor growth in immunocompetent mice by suppressing the activation, expansion and cytotoxicity of CD8 tumor-specific $\mathrm{T}$ cells. These findings provide new insight into the role of tumor-associated B7H4 in impairing T cell-mediated immunity and shaping the tumor microenvironment.

Acknowledgements The authors thank Prof. Lieping Chen and Prof. Liqun Luo for the kind gift of cell lines and antibody. The members of Fujian Medical University Public Technology Service Center and Laboratory Animal Center are also acknowledged.

Author contributions LZ and QZ conceived and designed the study; MR, YL and KW acquired patient samples and gathered clinical data; YZ and DF analysed and interpretated the data; LZ, MR and QZ drafted the manuscript; QZ supervised the study and reviewed the manuscript. All authors read and approved the final manuscript.

Funding This work was supported by the Natural Science Foundation of Fujian Province (Grant number 2017J01525), the Key Research Program of Fujian Provincial Health and Education Joint Committee (Grant number WKJ2016-2-31).

\section{Compliance with ethical standards}

Conflict of interest The authors declare that they have no conflicts of interest.

Ethical standards All procedures performed in studies involving human participants were in accordance with the ethical standards of the institutional and/or national research committee and with the 1964 Helsinki declaration and its later amendments or comparable ethical standards. All samples were obtained in accordance with the institutional policies. All protocols were reviewed and approved by the Ethical Committee of Fujian Medical University (2017-NO. 27). All procedures performed in studies involving animals were approved by the Fujian Medical University Institutional Animal Care and Use Committee (IACUC) in accordance with the ethical standards. Animal research approval number:
2017-031. All applicable international, national, and/or institutional guidelines for the care and use of animals were followed.

Informed consent All patients included in this study agreed to the use of their tumor tissue samples and data for research purposes prior to surgery via written informed consent.

Animal source Female C57BL/6 mice (on the $\mathrm{H}-2 \mathrm{~Kb}$ background), NOD-scid IL-2Rgnull (NSG) mice and T-cell receptor transgenic mice specific for $\mathrm{H}-2 \mathrm{~Kb}$ OVA257-264 (OT-I) at 6-8 weeks of age were purchased from Model Animal Research Center of Nanjing University. All mice were maintained in pathogen-free facilities.

Cell line authentication E0771 and GL261 were a generous gift from Professor Lieping Chen (Yale University, CT, USA). The phenotypes of these cell lines were verified by a Short Tandem Repeat analysis. MCF-7, SKBR-3, MDA-MB-468, EG7 and 4T1 were purchased from the American Type Culture Collection (Mabassas, USA), and these cell lines were authenticated there. Expression of B7H4 on EG7-B7H4 and GL261-B7H4 were verified by flow cytometry, as shown in Fig. 2. These cell lines were tested mycoplasma free. Phenotypes from cell morphology and growth rate were monitored regularly and did not change over time.

Open Access This article is licensed under a Creative Commons Attribution 4.0 International License, which permits use, sharing, adaptation, distribution and reproduction in any medium or format, as long as you give appropriate credit to the original author(s) and the source, provide a link to the Creative Commons licence, and indicate if changes were made. The images or other third party material in this article are included in the article's Creative Commons licence, unless indicated otherwise in a credit line to the material. If material is not included in the article's Creative Commons licence and your intended use is not permitted by statutory regulation or exceeds the permitted use, you will need to obtain permission directly from the copyright holder. To view a copy of this licence, visit http://creativecommons.org/licenses/by/4.0/.

\section{References}

1. 17th International Congress of Immunology (2019) Beijing, China. Eur J Immunol 49:1-2223 (Abstract P1561)

2. Choi IH, Zhu G, Sica GL, Strome SE, Cheville JC, Lau JS, Zhu Y, Flies DB, Tamada K, Chen L (2003) Genomic organization and expression analysis of $\mathrm{B} 7 \mathrm{H} 4$, an immune inhibitory molecule of the B7 family. J Immunol 171(9):4650-4654

3. Prasad DV, Richards S, Mai XM, Dong C (2003) B7S1, a novel B7 family member that negatively regulates $\mathrm{T}$ cell activation. Immunity 18(6):863-873

4. Sica GL, Choi IH, Zhu G, Tamada K, Wang SD, Tamura H, Chapoval AI, Flies DB, Bajorath J, Chen L (2003) B7H4, a molecule of the B7 family, negatively regulates $\mathrm{T}$ cell immunity. Immunity 18(6):849-861

5. Krambeck AE, Thompson RH, Dong H, Lohse CM, Park ES, Kuntz SM, Leibovich BC, Blute ML, Cheville JC, Kwon ED (2006) B7H4 expression in renal cell carcinoma and tumor vasculature: associations with cancer progression and survival. Proc Natl Acad Sci USA 103(27):10391-10396. https://doi. org/10.1073/pnas.0600937103

6. Zang X, Thompson RH, Al-Ahmadie HA, Serio AM, Reuter VE, Eastham JA, Scardino PT, Sharma P, Allison JP (2007) B7-H3 and $\mathrm{B} 7 \mathrm{x}$ are highly expressed in human prostate cancer and associated 
with disease spread and poor outcome. Proc Natl Acad Sci USA 104(49):19458-19463. https://doi.org/10.1073/pnas.0709802104

7. Quandt D, Fiedler E, Boettcher D, Marsch W, Seliger B (2011) B7H4 expression in human melanoma: its association with patients' survival and antitumor immune response. Clin Cancer Res 17(10):3100-3111. https://doi.org/10.1158/1078-0432. CCR-10-2268

8. Zang X, Loke P, Kim J, Murphy K, Waitz R, Allison JP (2003) B7x: a widely expressed B7 family member that inhibits $\mathrm{T}$ cell activation. Proc Natl Acad Sci USA 100(18):10388-10392. https ://doi.org/10.1073/pnas.1434299100

9. Kryczek I, Wei S, Zhu G, Myers L, Mottram P, Cheng P, Chen L, Coukos G, Zou W (2007) Relationship between B7H4, regulatory $\mathrm{T}$ cells, and patient outcome in human ovarian carcinoma. Cancer Res 67(18):8900-8905. https://doi.org/10.1158/0008-5472. CAN-07-1866

10. Dangaj D, Lanitis E, Zhao A, Joshi S, Cheng Y, Sandaltzopoulos R, Ra HJ, Danet-Desnoyers G, Powell DJ Jr, Scholler N (2013) Novel recombinant human $\mathrm{B} 7 \mathrm{H} 4$ antibodies overcome tumoral immune escape to potentiate T-cell antitumor responses. Cancer Res 73(15):4820-4829. https://doi.org/10.1158/0008-5472. CAN-12-3457

11. Rahbar R, Lin A, Ghazarian M, Yau HL, Paramathas S, Lang PA, Schildknecht A, Elford AR, Garcia-Batres C, Martin B, Berman HK, Leong WL, McCready DR, Reedijk M, Done SJ, Miller N, Youngson B, Suh WK, Mak TW, Ohashi PS (2015) B7H4 expression by nonhematopoietic cells in the tumor microenvironment promotes antitumor immunity. Cancer Immunol Res 3(2):184195. https://doi.org/10.1158/2326-6066.CIR-14-0113

12. Altan M, Pelekanou V, Schalper KA, Toki M, Gaule P, Syrigos K, Herbst RS, Rimm DL (2017) B7-H3 expression in NSCLC and its association with B7H4, PD-L1 and tumor-infiltrating lymphocytes. Clin Cancer Res 23(17):5202-5209. https://doi. org/10.1158/1078-0432.CCR-16-3107

13. Mugler KC, Singh M, Tringler B, Torkko KC, Liu W, Papkoff J, Shroyer KR (2007) B7H4 expression in a range of breast pathology: correlation with tumor T-cell infiltration. Appl Immunohistochem Mol Morphol 15(4):363-370. https://doi.org/10.1097/01. pai.0000213159.79557.71

14. Tringler B, Zhuo S, Pilkington G, Torkko KC, Singh M, Lucia MS, Heinz DE, Papkoff J, Shroyer KR (2005) B7H4 is highly expressed in ductal and lobular breast cancer. Clin Cancer Res 11(5):1842-1848. https://doi.org/10.1158/1078-0432. CCR-04-1658

15. Tringler B, Liu W, Corral L, Torkko KC, Enomoto T, Davidson S, Lucia MS, Heinz DE, Papkoff J, Shroyer KR (2006) B7H4 overexpression in ovarian tumors. Gynecol Oncol 100(1):44-52. https://doi.org/10.1016/j.ygyno.2005.08.060

16. Li J, Lee Y, Li Y, Jiang Y, Lu H, Zang W, Zhao X, Liu L, Chen Y, Tan H, Yang Z, Zhang MQ, Mak TW, Ni L, Dong C (2018) Co-inhibitory Molecule B7 Superfamily Member 1 Expressed by Tumor-Infiltrating Myeloid Cells Induces Dysfunction of Antitumor CD8(+) T Cells. Immunity 48(4):773.e5-786.e5. https:// doi.org/10.1016/j.immuni.2018.03.018

17. Chen L, Han X (2015) Anti-PD-1/PD-L1 therapy of human cancer: past, present, and future. J Clin Invest 125(9):3384-3391. https://doi.org/10.1172/JCI80011

18. Garaud S, Gu-Trantien C, Lodewyckx JN, Boisson A, De Silva P, Buisseret L, Migliori E, Libin M, Naveaux C, Duvillier H, Willard-Gallo K (2014) A simple and rapid protocol to nonenzymatically dissociate fresh human tissues for the analysis of infiltrating lymphocytes. J Vis Exp. https://doi.org/10.3791/52392

19. Kryczek I, Zou L, Rodriguez P, Zhu G, Wei S, Mottram P, Brumlik M, Cheng P, Curiel T, Myers L, Lackner A, Alvarez X, Ochoa A, Chen L, Zou W (2006) B7H4 expression identifies a novel suppressive macrophage population in human ovarian carcinoma. J Exp Med 203(4):871-881. https://doi.org/10.1084/jem.20050 930

20. Salceda S, Tang T, Kmet M, Munteanu A, Ghosh M, Macina R, Liu W, Pilkington G, Papkoff J (2005) The immunomodulatory protein $\mathrm{B} 7 \mathrm{H} 4$ is overexpressed in breast and ovarian cancers and promotes epithelial cell transformation. Exp Cell Res 306(1):128141. https://doi.org/10.1016/j.yexcr.2005.01.018

21. Miyatake T, Tringler B, Liu W, Liu SH, Papkoff J, Enomoto T, Torkko KC, Dehn DL, Swisher A, Shroyer KR (2007) B7H4 (DDO110) is overexpressed in high risk uterine endometrioid adenocarcinomas and inversely correlated with tumor T-cell infiltration. Gynecol Oncol 106(1):119-127. https://doi.org/10.1016/j.ygyno .2007 .03 .039

22. Sun Y, Wang Y, Zhao J, Gu M, Giscombe R, Lefvert AK, Wang $\mathrm{X}$ (2006) B7-H3 and B7H4 expression in non-small-cell lung cancer. Lung Cancer 53(2):143-151. https://doi.org/10.1016/j.lungc an.2006.05.012

Publisher's Note Springer Nature remains neutral with regard to jurisdictional claims in published maps and institutional affiliations. 